\title{
Interleukin 1 $\beta$-Responsive MicroRNA-146a Is Critical for the Cytokine-Induced Tolerance and Cross-Tolerance to Toll-Like Receptor Ligands
}

\author{
Md A. Nahid ${ }^{\text {a }}$ Minoru Satoh ${ }^{\text {b-d }}$ Edward K.L. Chan ${ }^{\text {a }}$ \\ Departments of a Oral Biology, ${ }^{b}$ Pathology, Immunology, and Laboratory Medicine and ${ }^{\mathrm{C}}$ Division of Rheumatology \\ and Clinical Immunology, Department of Medicine, University of Florida, Gainesville, Fla., USA; d Department of \\ Clinical Nursing, University of Occupational and Environmental Health, Kitakyushu, Japan
}

\section{Key Words}

Lipopolysaccharide · microRNA · Peptidoglycan · Toll-like receptor ligands

\begin{abstract}
Unwarranted overproduction of cytokines, such as interleukin (IL)- $1 \beta$, can cause moderate to severe pathological complications, and thus elaborate mechanisms are needed to regulate its onset and termination. One such, well-known, mechanism is endotoxin tolerance, generally described as controlling lipopolysaccharide Toll-like receptor 4 (LPSTLR4) signaling. Similarly, cytokine-induced tolerance plays an important role in regulating an overactive cytokine response. In this report, the capability of IL-1 $\beta$ to induce tolerance and cross-tolerance to various inflammatory ligands was investigated. IL-1 $\beta$-stimulated THP-1 monocytes showed a gradual increase of microRNA (miR)-146a, reaching 15 -fold expression by $24 \mathrm{~h}$. miR-146a upregulation induced tolerance toward subsequent challenges of IL-1 $\beta$, LPS, peptidoglycan, Pam and flagellin in THP-1 cells. The induction of tolerance was dependent on the IL-1 $\beta$ priming dose and associated increase of miR-146a expression. Moreover, IL-1 $\beta$-treated THP-1 cells showed sustained miR-146a upregulation that repressed IRAK1 and TRAF6 adaptor molecules. Transfection of miR-146a alone mimicked IL-1 $\beta$ induced tolerance in monocytes, while cells transfected with
\end{abstract}

miR-146a inhibitor increased chemokine production. A comparable cytokine response regulated by miR-146a was also detected in lung epithelial A549 cells, purified human monocytes and mouse peritoneal macrophages. Thus, our studies showed that miR-146a was crucial for monocytic cell-based IL-1 $\beta$ tolerance and cross-tolerance, and thus opens the way for future research in the development of therapeutics for inflammatory diseases.

(c) 2015 S. Karger AG, Basel

\section{Introduction}

The innate immune system, which acts against microbial assault, consists of several distinct components. Cytokines are important effector molecules which contribute immensely to host immunity by inhibiting and/or eliminating invading pathogens and promoting tissue repair. They are produced through recognition of microbial danger signals by pattern recognition receptors that are commonly found on the surface of innate immune cells such as monocytes and macrophages [1]. Among the pattern recognition receptors, Toll-like receptors (TLRs) act as major sensors for generating the inflammatory network [2].

Tumor necrosis factor (TNF)- $\alpha$ and interleukin (IL)$1 \beta$ are two of the most potent initial cytokines secreted

\section{KARGER 125}

(c) 2015 S. Karger AG, Base

$1662-811 \mathrm{X} / 15 / 0074-0428 \$ 39.50 / 0$

E-Mail karger@karger.com

www.karger.com/jin
Prof. Edward K.L. Chan

Department of Oral Biology, University of Florida

1395 Center Drive

Gainesville, FL 32610-0424 (USA)

E-Mail echan@ufl.edu 
during innate immune activation by TLR ligand stimulation. IL- $1 \beta$ is stimulated by inflammatory TNF- $\alpha$ or IL- $1 \beta$ itself in many cell types $[3,4]$. Blood monocytes, tissue macrophages and dendritic cells are the main source of IL-1 $\beta$; however, it is also produced by natural killer cells and $\mathrm{B}$ lymphocytes. Before its secretion, the inactive proIL- $1 \beta$ is processed by IL- $1 \beta$-converting enzyme (caspase-1), leading to its maturation [4-6]. Upon secretion, IL-1 $\beta$ produces signals for IL-1 receptor type I (IL-1RI), forming a heterodimer with a second transmembrane molecule, the IL-1R accessory protein (IL-1RAcP). Members of the TLR and IL-1R families possess a common 200 -amino acid region in their cytoplasmic tails called the Toll-IL-1R (TIR) domain, which plays an important role in transducing the signals through this receptor [7]. The cytosolic Toll/TIR domain binds and recruits adaptor molecules that eventually activate many specific transcription factors. Thus, IL- $1 \beta$ signaling induces the activation of NF- $\kappa B$, AP-1 (activator protein-1) and JNK pathways by recruiting MyD88, IL-1R-associated kinases (IRAK1, IRAK2 and IRAK4), TNFR-associated factor 6 (TRAF6) and TGF- $\beta$-activated kinase. The nuclear translocated (activated) NF- $\kappa$ B causes transcription of various proinflammatory genes, which together orchestrate the early response for the elimination of infections or sterile insults, subsequent repair and the shaping of adaptive immunity $[8,9]$. Although an immediate and transient activation of NF- $\kappa \mathrm{B}$ is important for the normal physiological response to pathogens, uncontrolled synthesis and release of cytokines is implicated in the pathogenesis of various diseases including, but not limited to, type 1 and type 2 diabetes, atherosclerosis, metabolic syndrome, neuroinflammatory diseases and inflammatory bowel disease $[3,4,10]$. The overwhelming production of IL- $1 \beta$ also causes tissue injury by the continuous infiltration of leukocytes to the site of infection. In order to avoid such immunopathology and to prevent the onset of autoimmune and/or inflammatory disorders, IL- $1 \beta$ production needs to be tightly regulated in a timely manner by a number of endogenous and/or inducible genes [11-15]. Further studies are thus needed to examine the critical role of such genes that can limit the magnitude and duration of the inflammatory response by regulating IL-1 signaling.

MicroRNAs (miRNAs) are important regulators of gene expression essential for many biological processes, ranging from embryonic development, organogenesis and human inflammatory diseases [16], most importantly those in the mammalian immune system $[17,18]$. During innate immune activation, a few miRNAs are ex-

miR-146a Mediates IL-1-Induced Tolerance pressed in response to cognate TLR ligands, with a consensus emerging that miRNA-146a (miR-146a), miR-132, miR-155 and miR-21 are important to regulate the activation of the inflammatory cascade in myeloid cells [11, 12, 19-21]. Of note, miR-146a and miR-132 are central for TLR 4 and TLR2 signaling, respectively $[11,12]$. There are reports that inflammatory cytokines markedly increase the expression of miR-146a and miR-155 in various cell types [22-24]. Notably, miR-146a expression is induced by TNF- $\alpha$ and IL- $1 \beta$, implying its broader impact in immunity $[22,25]$. Along this line, prior studies have shown that NF- $\mathrm{BB}$-dependent miR-146a induction is critical for innate immunity because of its important molecular targets, which include adaptor kinases $[11,22$, 26].

IRAK1/2 and TRAF6 are two important signaling adaptor kinases downstream of TLR (except for TLR3) signal transduction. Through TLR activation, these adaptor kinases promote inflammation which is sustained by inflammatory cytokines or chemokines. To understand the pleiotropic effect of these mediators is an ongoing major focus of innate immunity research. The TLR4 signaling cascade has been profoundly studied in terms of endotoxin tolerance $[11,14]$. Endotoxin tolerance is defined as a state of hyporesponsiveness to lipopolysaccharide (LPS) stimulation after an earlier exposure and is important in preventing overproduction of the immune response to the invading pathogen.

In parallel to LPS tolerance, IL- $1 \beta$-induced tolerance has been studied both in vitro and in vivo [25, 27]; however, its mechanism and beneficial significance are poorly understood in terms of the role of miRNA. Our recent reports have shown that miR-146a is critical for LPS-induced tolerance [11] and cross-tolerance [14] in monocytic cells by repressing IRAK1 and TRAF6 adaptor molecules. IRAK1 and TRAF6 are also identified as the major adaptor kinases in the IL- $1 \beta$ signaling pathway $[11,22]$. Due to sharing of the same adaptor molecules, miR-146a appears to have a regulatory effect on IL- $1 \beta$ signaling. We hypothesize that overactive IL- $1 \beta$ signaling can be controlled through the tolerance mechanism provided by the action of miR-146a. The aim of this study was to investigate the effect of sustained miR-146a expression in IL-1 $\beta$ primed monocytic cells on the subsequent release of mediators, using a similar experimental LPS tolerance setup as in previous studies $[11,14]$. Our findings highlight the importance of investigating the role of miR-146a in inducing tolerance in IL- $1 \beta$ primed monocytes and in modulating innate immunity to prevent excessive inflammation and tissue injury caused by microbial infection. 


\section{Materials and Methods}

Cell Culture and Stimulation with Cytokines and TLR Ligands

Human THP-1 cells, an undifferentiated monocytic cell line, were obtained from the American Type Culture Collection (Manassas, Va., USA). Cells were maintained by twice weekly passage in RPMI 1640 medium supplemented with 25 mM HEPES and L-glutamine (BioWhittaker, Walkersville, Md., USA), 10\% FBS (Mediatech, Manassas, Va., USA) and $100 \mathrm{U} / \mathrm{ml}$ penicillinstreptomycin (Mediatech) at $37^{\circ} \mathrm{C}$ with $5 \% \mathrm{CO}_{2}$. Log-phase cells were used in all experiments and cultured at a density of $10^{6}$ cells/ $\mathrm{ml}$ with a viability of $>99 \%$. To determine the kinetics of cytokine-induced miRNA expression, fresh THP-1 monocytes were suspended in complete RPMI 1640 culture medium and seeded at $10^{6}$ cells $/ \mathrm{ml}$. THP-1 cells were stimulated with the following human cytokines: TNF- $\alpha(10 \mathrm{ng} / \mathrm{ml}), \mathrm{IL}-1 \beta(50 \mathrm{ng} / \mathrm{ml})$, interferon (IFN)- $\alpha$ (10 ng/ml), IL-8 (10 ng/ml) and IL-6 (10 ng/ml) (BD Biosciences, Franklin Lakes, N.J., USA) for 8 or 24 h. Highly purified Salmonella enterica serotype Minnesota LPS (100 ng/ml) stimulation was used as a positive control [11]. In other studies, A549 lung epithelial cells (nonresponsive to LPS) were used instead of THP-1 cells and were treated with IL-1 $\beta$ (0.01 to $1 \mathrm{ng} /$ $\mathrm{ml})$ or LPS $(100 \mathrm{ng} / \mathrm{ml})$ for $3,6,12$ or $24 \mathrm{~h}$. Mouse macrophages were from 3 -month-old female C57BL/6 mice, which had been intraperitoneally injected with $0.5 \mathrm{ml}$ of $4 \%$ sodium thioglycollate 3 days earlier as described [14]. Peritoneal cells (approx. 90\% macrophages) were harvested by lavage of the peritoneal cavity, and were then grown in supplemented DMEM. Mouse macrophages were treated with IL-1 $\beta(100 \mathrm{ng} / \mathrm{ml})$ for $24 \mathrm{~h}$. Cytokine stocks were prepared in tissue culture-grade PBS and preserved at $-80^{\circ} \mathrm{C}$ until use. Cells were harvested and pellets were washed in PBS followed by flash freezing and stored at $-80^{\circ} \mathrm{C}$ for total RNA isolation and subsequent analysis. Human peripheral blood mononuclear cells (Precision Bioservices, Md., USA) were used for monocyte preparation using an EasySep ${ }^{\mathrm{TM}}$ human monocyte enrichment kit without CD16 depletion (Stem Cell Technologies, B.C., Canada).

\section{In vitro Induction of IL-1 $\beta$ Tolerance}

An IL-1 $\beta$-induced tolerance cell model using THP-1 cells was adapted from methods described previously [27] with some minor modifications. Briefly, log-phase THP-1 cells were transferred to fresh complete medium in new 5- or 25-ml flasks at $5 \times 10^{5}$ cells $/ \mathrm{ml}$. Cells were incubated with IL-1 $\beta$ (50 or $100 \mathrm{ng} /$ $\mathrm{ml}$ ) for $18 \mathrm{~h}$. After two washes with tissue culture-grade PBS, cells in complete culture medium $\left(10^{6}\right.$ cells $\left./ \mathrm{ml}\right)$ alone (untolerized negative control) or with the same or different inflammatory stimulators such as LPS $(1,000 \mathrm{ng} / \mathrm{ml})$, peptidoglycan (PGN, $500 \mathrm{ng} / \mathrm{ml}), \mathrm{Pam}_{3} \mathrm{CSK}_{4}(\mathrm{Pam}, 100 \mathrm{ng} / \mathrm{ml})$ and flagellin $(100 \mathrm{ng} / \mathrm{ml})$ were cultured in a 24 -well plate. Similarly, to observe the IL-1 $\beta$-induced tolerance efficiency in primary cells, mouse peritoneal macrophages and human monocytes were primed with IL-1 $\beta$ (100 ng/ml) in 24 -well plates followed by washing and challenged with LPS, PGN or Pam. After incubation for 5 or $24 \mathrm{~h}\left(37^{\circ} \mathrm{C}\right.$ and $\left.5 \% \mathrm{CO}_{2}\right)$, supernatants were harvested by centrifugation $\left(1,500 \mathrm{~g}\right.$ at $4^{\circ} \mathrm{C}$ for $\left.5 \mathrm{~min}\right)$ and immediately stored at $-80^{\circ} \mathrm{C}$ until assayed for the release of mediators (TNF- $\alpha$, IL-8 or RANTES). The cell pellets were washed in PBS, followed by flash-freezing, and were stored at $-80^{\circ} \mathrm{C}$ for total RNA isolation.
Quantification of miRNA and mRNA Expression Levels by $q R T-P C R$

Total RNA of cytokine-treated THP-1 cells or A549 cells were isolated using the mirVana Total RNA isolation kit (Life Technologies) following the manufacturer's protocol. RNA yield and purity were determined using the NanoDrop ND-1000 spectrophotometer (NanoDrop Technology, Wilmington, Del., USA). Quantification of mature miRNA expression was performed using the TaqMan qRT-PCR as described [11,28-30]. Equal amounts of each RNA (6.7 ng for miRNA and $33 \mathrm{ng}$ for mRNA) were used for quantitative real-time RT-PCR (qRT-PCR) analysis. For mRNA analysis, a high-capacity cDNA RT kit (Applied Biosystems) and TaqMan mRNA assay primers for mRNA expression were used. The cycle threshold values, corresponding to the PCR cycle number at which fluorescence emission reaches a threshold above baseline emission, were determined. miRNA expression values were calculated using RNU44 as an endogenous control (Applied Biosystems) following the $2^{-\Delta \Delta C t}$ method [31]. mRNA expression values were quantified in the same way after normalization to mammalian $18 \mathrm{~S}$ rRNA as previously described $[11,12,14]$.

\section{Transfection Assay}

miR-146a functional analyses were performed using synthetic miR-146a-mimic and miR-146a inhibitor (anti-miRNA inhibitor) transfection as described [11]. One day before the transfection, THP- 1 cells were transferred to fresh culture medium at a concentration of $5 \times 10^{5}$ cells $/ \mathrm{ml}$. The following day, THP- 1 cells adjusted to $5 \times 10^{5}$ cells/well were transfected with $100 \mathrm{nM}$ of miR-146amimic or inhibitor using Lipofectamine 2000 (Invitrogen), according to the manufacturer's instructions. MiR-146a-mimictransfected THP-1 cells were incubated for $24 \mathrm{~h}$, followed by washing twice with complete growth medium. The washed cells were treated with LPS, PGN or IL- $1 \beta$ for 5 or $24 \mathrm{~h}$. For miR-146a inhibitor experiments, transfected THP-1 cells were incubated for 24 $\mathrm{h}$, followed by washing with complete growth medium. Cells were then challenged with various ligands for 5 or $24 \mathrm{~h}$. Similarly, A549 cells were transfected with $100 \mathrm{nM}$ miR-146a-mimic or miR-146a inhibitor followed by IL-1 $\beta(100 \mathrm{ng} / \mathrm{ml})$ treatment. Supernatants from the cell cultures were collected and assayed for mediator release and cell pellets were used for RNA isolation and qRT-PCR analysis.

\section{Enzyme-Linked Immunosorbent Assay}

Supernatants were collected from cell cultures at different time points after stimulation with various concentrations of stimulators such as cytokines and LPS. Secreted TNF- $\alpha$, IL-8 (Opt EIA kit) and RANTES (R\&D systems) proteins in supernatants were measured by ELISA. Absorbance was measured at $405 \mathrm{~nm}$ using a microplate reader (Model 680, Bio-Rad). $\mathrm{A}_{405}$ was converted into concentrations using standard curves of the respective recombinant human proteins as previously reported [11].

\section{Western Blot Analysis}

Preparation of cell lysates and Western blot analysis were modified from our previous publications $[11,32,33]$. IL-1 $\beta$-primed and unprimed THP- 1 cells $\left(5 \times 10^{6} /\right.$ condition $)$ were collected $18 \mathrm{~h}$ after IL- $1 \beta$ challenge, pelleted at $1,000 \mathrm{~g}$ for $10 \mathrm{~min}$ and lysed on ice for $10 \mathrm{~min}$ in $1 \mathrm{ml}$ of lysis buffer (50 mM HEPES, pH 7.6, $150 \mathrm{~mm} \mathrm{NaCl}, 1 \mathrm{~mm}$ EDTA, 1\% Nonidet P-40, $20 \mathrm{~mm}$ $\beta$-glycerophosphate, $1 \mathrm{mM} \mathrm{Na} \mathrm{VO}_{4}, 1 \mathrm{mM} \mathrm{NaF}, 1 \mathrm{~mm}$ benzami- 


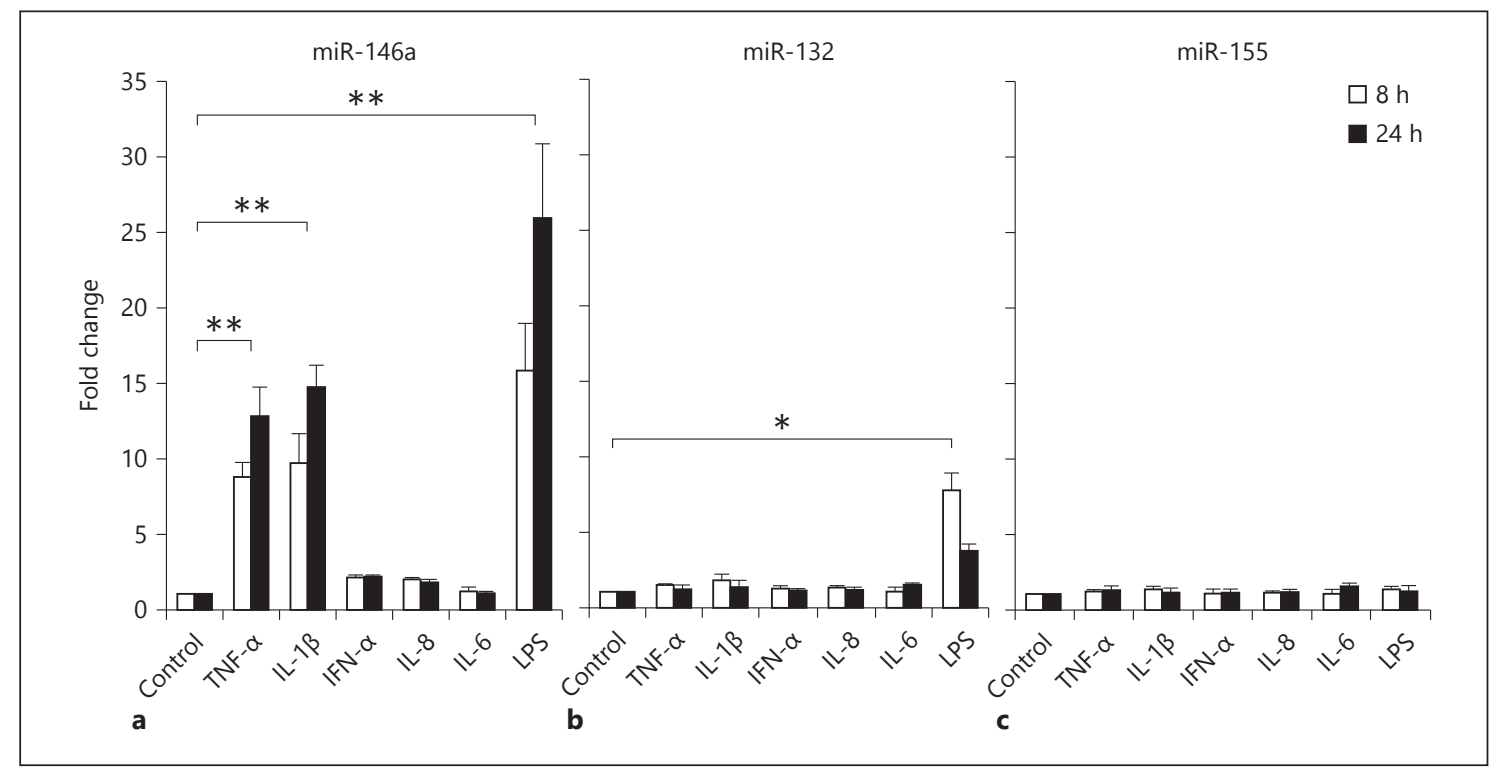

Fig. 1. miRNA expression kinetics in cytokine-stimulated monocytes. THP-1 cells were treated with different cytokines (at concentrations of $10 \mathrm{ng} / \mathrm{ml}$, except for IL- $1 \beta$ at $50 \mathrm{ng} / \mathrm{ml}$ ) or LPS (100 ng/ $\mathrm{ml}$ ) as a positive control and incubated for 8 or $24 \mathrm{~h}$. Total RNA was purified from the respective cell pellets and analyzed by
TaqMan qRT-PCR for the expression of miR-146a (a), miR-132 (b) and miR-155 (c). miRNA expression was normalized to the level of control RNA RNU44. All results are expressed as mean \pm SD from 3 independent experiments. ${ }^{*} \mathrm{p}<0.05$; ${ }^{* *} \mathrm{p}<0.01$ (twotailed unpaired $t$ test) compared with untreated control cells.

\section{Results}

and complete protease inhibitor mixture from Roche Diagnostic, Indianapolis, Ind., USA). Supernatants were collected after centrifugation at $13,000 \mathrm{rpm}$ for $20 \mathrm{~min}$ at $4^{\circ} \mathrm{C}$. Similarly, A549 cell lysates were prepared after 3,6 or 24 h of IL-1 $\beta(1 \mathrm{ng} / \mathrm{ml})$ treatment. miR-146a-mimic- or miR-146a inhibitor-transfected cell lysate was also prepared. Protein concentration in the soluble lysates was quantitated using a Bio-Rad protein assay kit (Bradford), separated by SDS-PAGE (10\% acrylamide; Bio-Rad) along with Precision Plus Protein standards (Bio-Rad), and electrotransferred to a nitrocellulose membrane (Bio-Rad). The membranes were blocked for $1 \mathrm{~h}$ at room temperature or overnight at $4^{\circ} \mathrm{C}$ with $5 \%$ nonfat milk in PBS/0.05\% Tween 20 (PBS-T), and were probed with primary rabbit anti-IRAK1 (1:300) or anti-TRAF6 (1:300) antibody (Santa Cruz Biotechnology, Santa Cruz, Calif., USA). The membranes were washed 3 times with PBS-T and incubated for $1 \mathrm{~h}$ with goat anti-rabbit IgG-HRP at a concentration of 1:5,000 (Southern Biotech, Birmingham, Ala., USA). After washing in PBS-T, reactive protein bands were visualized by SuperSignal Pico chemiluminescent reagent (Pierce, Rockford, Ill., USA). As a loading control, tubulin was blotted with mouse anti-tubulin monoclonal antibodies (1:5,000; Sigma-Aldrich, St. Louis, Mo., USA). Semi-quantitative analyses of band intensities were performed using ImageJ software (http://rsbweb.nih.gov/ij/) normalized to tubulin.

\section{Statistical Analysis}

Data are presented in the figures as mean \pm SE. Student's t test (two-tailed) was used to compare data between groups, except where mentioned otherwise. Prism for Windows version 6.0 (GraphPad Software, San Diego, Calif., USA) was used, and $\mathrm{p}<$ 0.05 was considered statistically significant.

miR-146a Mediates IL-1-Induced Tolerance

\section{Proinflammatory Cytokine-Induced miR-146a}

Expression in Innate Immune Cells

The MyD88-dependent TLR signaling cascade plays a defensive role in the host innate immune system by producing various proinflammatory cytokines. Simultaneously, certain TLR signaling-associated miRNAs are involved in immunoregulatory processes $[34,35]$. TLR4 ligand (LPS)-induced miR-146a is important in innate immunity for regulating adaptor kinases that are responsible for NF- $\kappa B$ activation. Additionally, a few other TLR ligand-induced miRNAs (miR-132/212, miR-155 and miR-21) have been reported to affect the immune system $[12,13]$. In contrast, very few cytokines have been reported to induce immunoregulatory miRNA $[14,22]$. Considering that miRNA expression can be affected by the binding of various TLR ligands, we were interested in evaluating the capacity of a range of cytokines to induce the production of specific miRNA that we previously reported to be of relevance to the innate immune response $[12,13]$.

In this study, the expression kinetics of miR-146a, miR-155, miR-132/-212, miR-21 and miR-16 were investigated in THP-1 monocytes in response to treatment with common cytokines such as TNF- $\alpha$, IL- $1 \beta$, IFN- $\alpha$, IL- 8 and IL-6 (fig. 1a-c). The fold changes in miRNA ex- 
pression were calculated by comparing the value of cytokine-treated cells to that of untreated cells cultured in parallel. Among these cytokines, only TNF- $\alpha$ and IL- $1 \beta$ induced a significant $(\mathrm{p}<0.01)$ increase in miR-146a expression from 8 - to 10 -fold at $8 \mathrm{~h}$ up to 12 - to 14 -fold at $24 \mathrm{~h}$; this pattern is analogous to that observed in LPSstimulated monocytes (fig. 1a). A similar pattern of miR146a expression was observed previously at the 8-hour time point $[14,22]$. In contrast, miR-132, miR-155 (fig. 1b, c), miR-16, miR-212 and miR-21 did not show significant changes after treatment with the tested cytokines at 8 or $24 \mathrm{~h}$ (data not shown). In addition to miR146a, LPS also induced the production of miR-132, but not miR-155, in THP-1 cells [12]. Primary mouse peritoneal macrophages were also examined for miR-146a expression after IL- $1 \beta$ or TNF- $\alpha$ stimulation. As expected, miR-146a showed a continual increase up to 14-fold and 15 -fold $24 \mathrm{~h}$ after TNF- $\alpha$ and IL- $1 \beta$ stimulation, respectively (data not shown). Unlike TNF- $\alpha$, IL- $1 \beta$ receptor signaling uses cytosolic Toll/IL-1R domain and IRAK1 and TRAF6 adaptor molecules (miR-146a targets) to activate and amplify transcription for proinflammatory cytokines. In order to advance our understanding of the dynamic nature of IL- $1 \beta$-induced miR-146a, we focused on its biological significance in the subsequent experiments.

\section{miR-146a May Account for IL-1 $\beta$-Induced Self- and}

Cross-Tolerance to a Panel of Innate Immune Ligands

Taking into account our previous findings that the expression of miR-146a was critical for low-dose LPS-induced refractoriness to a high dose of LPS [11], we investigated whether IL-1 $\beta$, an early LPS-induced cytokine, could induce an LPS-tolerant state. Although IL- $1 \beta$ stimulation in human peripheral blood mononuclear cells is known to induce TNF- $\alpha$ production [36], IL- $1 \beta$ does not induce TNF- $\alpha$ production in naïve THP-1 cells [25]. So IL-1 $\beta$-induced homologous tolerance has been studied based on the reduction of the release of chemokines such as IL-8 and RANTES. The low production of proinflammatory cytokines, including TNF- $\alpha$, is a characteristic of tolerance to endotoxins, so we evaluated cross-tolerance via the production of TNF- $\alpha$ in IL-1 $\beta$-primed monocytes in response to a challenge dose of LPS, PGN, Pam or flagellin. The ability of IL- $1 \beta$ to induce homologous (self-) and heterologous (cross-) tolerance to a panel of bacterial ligands was observed using the THP- 1 cell model system (fig. $2 \mathrm{a}-\mathrm{d}$ ). THP-1 cells were primed with IL-1 $\beta$ (50 $\mathrm{ng} / \mathrm{ml}$ ) for $18 \mathrm{~h}$, followed by challenge with various inflammatory ligands. After $5 \mathrm{~h}$ of incubation with LPS,
PGN, Pam, flagellin or IL-I $\beta$, levels of cytokine release were analyzed compared to untolerized controls. TNF- $\alpha$ levels decreased significantly by $40.9-75.6 \%$ after secondary challenges with LPS (71.4\%), PGN (75.6\%), Pam (68.4\%) and flagellin (40.9\%; fig. 2a). These studies are consistent with those previously reported [27]. As expected, TNF- $\alpha$ production was not observed in either unprimed or IL-1 $\beta$-primed THP-1 cells (fig. $2 \mathrm{a}$ ). TNF- $\alpha$ mRNA levels, measured by qRT-PCR analysis, were consistent with the changes in protein expression in crosstolerized THP-1 monocytes, and reduction of this TNF- $\alpha$ mRNA was significant when compared with the untolerized control (data not shown). Additionally, IL-1 $\beta$ primed THP-1 monocytes showed significant reductions in IL-8 (fig. 2b) and RANTES (fig. 2c) after challenge with LPS, PGN, Pam, flagellin or IL-1 $\beta$. Having examined the tolerance in IL-1 $\beta$-primed THP-1 monocytes, we further investigated whether there was any link between miR-146a expression and the observed hyporesponsiveness.

In our previous study, LPS-induced expression of miR146a was shown to remain at a high level, which has been shown to be responsible, in large part, for maintaining tolerance and cross-tolerance $[11,13,14]$. The expression of miR-146a was measured in the tolerized THP-1 cells (fig. 2d). As expected, tolerized cells showed profoundly higher miR-146a expression over $18 \mathrm{~h}$ of initial incubation plus $5 \mathrm{~h}$ of challenge compared to untolerized cells which were only exposed to $5 \mathrm{~h}$ of challenge with the indicated ligands. In contrast, under similar conditions, miR-155 had no change in expression over the same time period in these THP-1 cells (data not shown). IRAK1 and TRAF6 are the known molecular targets of miR-146a [22], and knockdown of these adaptors in the MyD88 signaling pathway impaired cytokine response [14]. In order to verify the role of miR-146a in IL-1 $\beta$-induced tolerance, expression of these two adaptors was examined by Immunoblot analysis. IRAK1 and TRAF6 were moderately reduced in IL-1 $\beta$ - tolerized cells (fig. 2e), similar to the previous report [37].

To extend the investigation of IL- $1 \beta$-induced tolerance in the THP-1 cell model, primary mouse peritoneal macrophages and human monocytes were also examined for a similar cross-tolerance mechanism with IL- $1 \beta$. TNF- $\alpha$ production decreased by $40-50 \%$ in IL$1 \beta$-primed macrophages or monocytes after challenge with LPS, PGN or Pam compared to unprimed controls (fig. 2f, h). As expected, a 5- to 8-fold increase in miR146 a expression was observed in the IL- $1 \beta$-tolerized cells (fig. $2 \mathrm{~g}, \mathrm{i}$ ), consistent with its potential role in providing tolerance in primary mouse and human cells. An inter- 


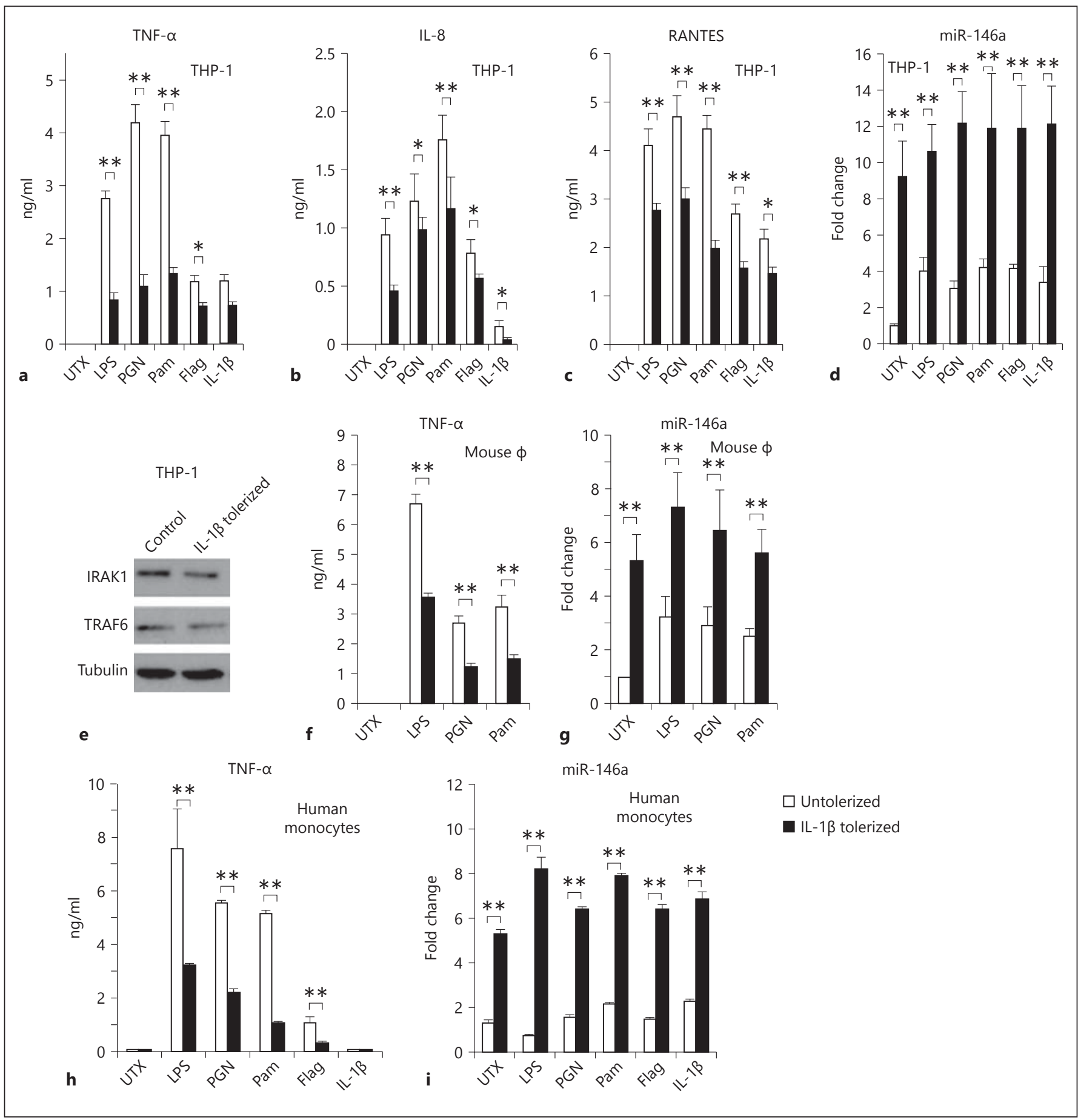

Fig. 2. The high levels of miR-146a produced may account for the IL- $1 \beta$-induced cross-tolerance. THP-1 cells primed with $50 \mathrm{ng} / \mathrm{ml}$ IL- $1 \beta$ for $18 \mathrm{~h}$ and untolerized cells incubated for the same time period were washed twice with PBS, then challenged with the various ligands indicated for $5 \mathrm{~h}$. Culture supernatants were analyzed for cytokines and chemokines using ELISA (a-c) and total RNA was examined for miR-146a (d) by qRT-PCR. Changes in IRAK1 and TRAF6 protein levels in IL-I $\beta$-primed and untolerized (control) THP-1 cells for $18 \mathrm{~h}$ were analyzed by Western blot with tu- bulin expression shown as loading controls (e). Mouse primary macrophages $(\mathbf{f}, \mathbf{g})$ and human monocytes $(\mathbf{h}, \mathbf{i})$ primed with or without IL-1 $\beta(100 \mathrm{ng} / \mathrm{ml})$ for $18 \mathrm{~h}$ were likewise examined for IL1 -induced cross-tolerance once challenged with TLR ligands for $5 \mathrm{~h}$. TNF- $\alpha$ production was quantitated by ELISA (f, h) and miR146a expression by qRT-PCR $(\mathbf{g}, \mathbf{i})$. All results are expressed as mean \pm SD from 3 independent experiments. ${ }^{*} \mathrm{p}<0.05 ;{ }^{* *} \mathrm{p}<0.01$, compared with IL-1 $\beta$-tolerized and untolerized cells. Flag = Flagellin; UTX = untreated control. 


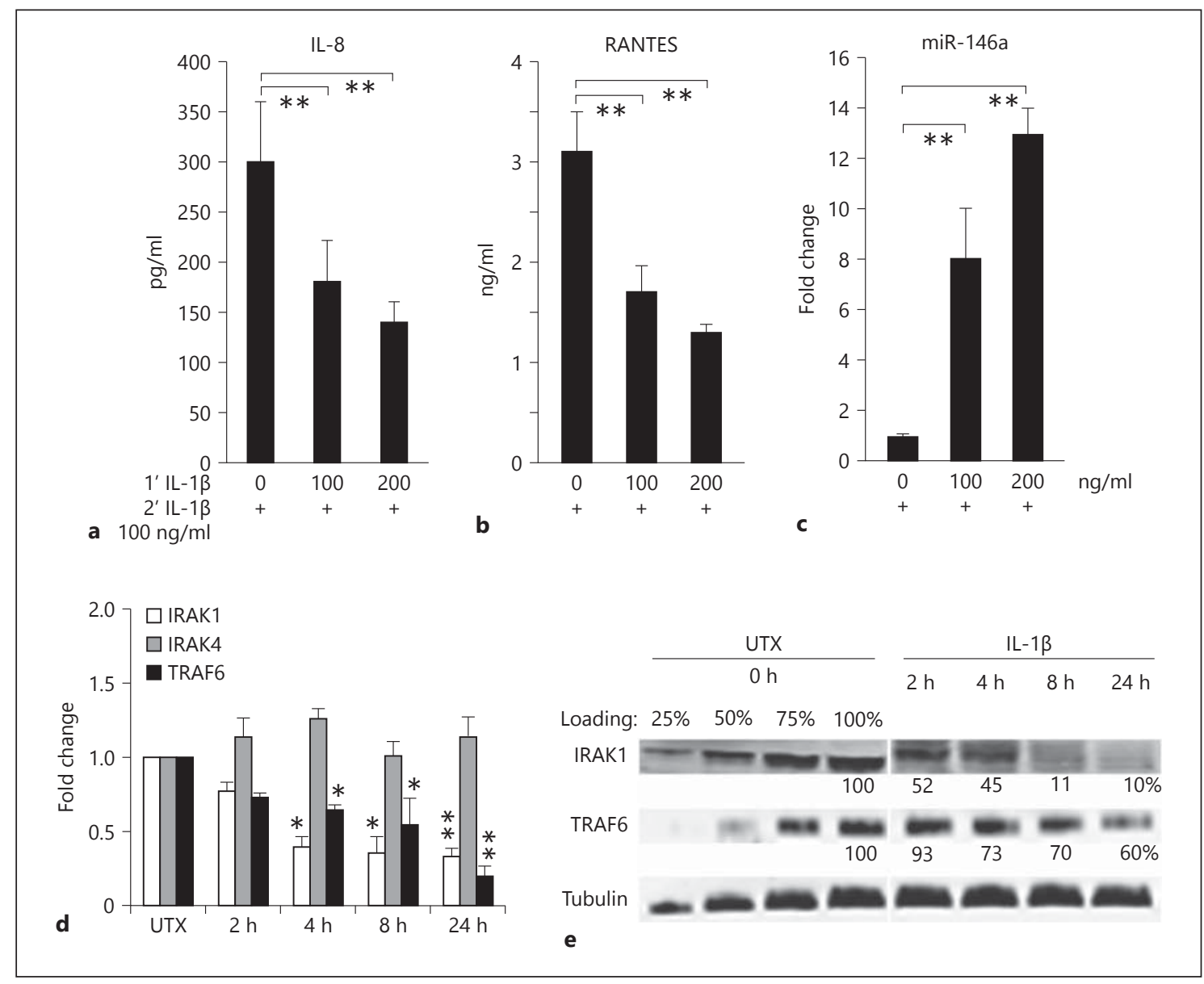

Fig. 3. Dose-dependent IL-1 $\beta$ priming generates efficient tolerance, which is inversely correlated to the level of induced miR146a. THP-1 cells were primed with 0,100 or $200 \mathrm{ng} / \mathrm{ml} \mathrm{IL-1 \beta}$ continuously for $18 \mathrm{~h}$, washed twice with PBS and then challenged with $100 \mathrm{ng} / \mathrm{ml} \mathrm{IL}-1 \beta$. Supernatants and cell pellets were collected $5 \mathrm{~h}$ later for IL- 8 and RANTES protein assay by ELISA (a, b) and miR-146a expression analysis in total RNA (c), respectively. The

pretation of these results is that miR-146a appears to play an important role in IL- $1 \beta$-induced tolerance based on the inverse correlation with cytokine or chemokine production and levels of IRAK1 and TRAF6 adaptor molecules.

Higher-Dose IL-1 $\beta$ Priming Renders a Higher Level of miR-146a Expression and More Efficient Suppression of Chemokine Production

In figure $2, \mathrm{IL}-1 \beta$-induced cross-tolerance was observed using a low priming dose; this was also reported by other investigators $[25,27]$. However, during infection, the host might experience a higher level of IL-1 $\beta$ production, partly due to overactivation of the TLR sig- relative expression levels of IRAK1, IRAK4 and TRAF6 mRNA were examined at 2, 4,8 and $24 \mathrm{~h}$ after the $1-\mathrm{ng} / \mathrm{ml}$ IL- $1 \beta$ challenge (d). Western blot analysis was performed for IRAK1, TRAF6 and tubulin in the cell lysates collected at the same time points (e). All results are expressed as mean \pm SD from 3 independent experiments. ${ }^{* *} \mathrm{p}<0.01$, compared to untolerized control (UTX).

naling pathways. In order to better understand the impact of the IL- $1 \beta$ priming dose and related miR-146a expression on tolerance, priming concentrations for THP- 1 cells from 100 to $1,000 \mathrm{ng} / \mathrm{ml}$ were used, followed by challenge with $100 \mathrm{ng} / \mathrm{ml}$ of IL-1 $\beta$. Priming with $100 \mathrm{ng} / \mathrm{ml}$ of IL- $1 \beta$ resulted in a $43.3 \%$ decrease in IL- 8 and $45 \%$ decrease in RANTES production ( $\mathrm{p}<0.01$; fig. 3a, b). This reduction increased up to $56.7 \%$ for IL-8 and $58.3 \%$ for RANTES, with the increase of IL- $1 \beta$ priming concentration to $200 \mathrm{ng} / \mathrm{ml}$. In contrast, priming with $5-10 \mathrm{ng} / \mathrm{ml}$ of IL-1 $\beta$ showed little or no induced tolerance (data not shown); this lack of an effect from low-dose IL-1 priming is consistent with that in an earlier report [27]. The dose-dependence of this IL-1 $\beta$ 


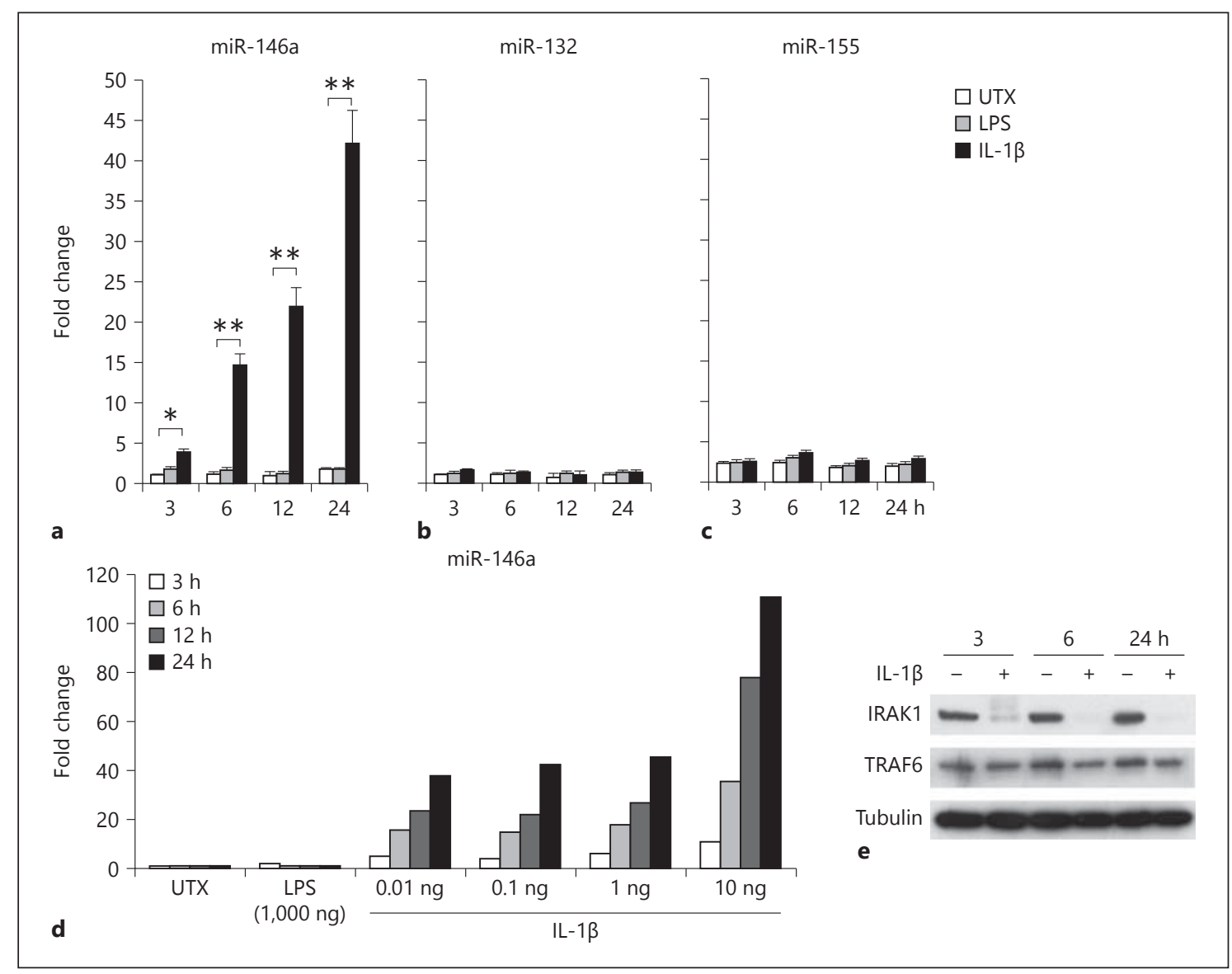

Fig. 4. Induced miR-146a accounts for IRAK1 and TRAF6 repression in IL- $1 \beta$ stimulated A549 cells. A549 cells treated with $1 \mathrm{ng} / \mathrm{ml}$ IL- $1 \beta$ or $100 \mathrm{ng} / \mathrm{ml}$ LPS for $3,6,12$ or $24 \mathrm{~h}$ and total RNA were analyzed by qRT-PCR for the expression of miR-146a (a), miR-132 (b) and miR-155 (c). IL-1 $\beta$ induced a dose-dependent expression of miR-146a (d). Changes in IRAK1 and TRAF6 protein levels in

priming effect was also clearly correlated with the reduction of TNF- $\alpha$ after cross-challenge with LPS, PGN or Pam (data not shown), and is similar to previous observations under in vitro and in vivo conditions [27]. A gradual increase of miR-146a up to 13-fold was observed at $200-\mathrm{ng} / \mathrm{ml} \mathrm{IL-1} \beta$ priming (fig. 3c) and this correlated with efficient tolerance. The relative expression levels of IRAK1, IRAK4 and TRAF6 mRNA were examined at 2, 4,8 and $24 \mathrm{~h}$ after the $1-\mathrm{ng} / \mathrm{ml}$ IL- $1 \beta$ challenge (fig. $3 \mathrm{~d}$ ). Immunoblot analysis confirmed the moderate, gradual reduction in IRAK1 and TRAF6 levels with the increase of priming concentrations from 100 to $200 \mathrm{ng} / \mathrm{ml}$ (fig. 3e). The repression of these adaptor molecules reflects the impact of miR-146a on chemokine reduction and IL-1 $\beta$-induced tolerance or cross-tolerance in a priming dose-dependent manner.

miR-146a Mediates IL-1-Induced Tolerance
IL-I $\beta$-treated and untreated A549 cells at 3, 6 or 24 h were analyzed by Western blot with tubulin expression shown as loading controls (e). All results are expressed as mean \pm SD from 3 independent experiments. ${ }^{*} \mathrm{p}<0.05 ;{ }^{* *} \mathrm{p}<0.01$, compared with untreated control (UTX).

\section{IL-1 $\beta$-Induced miR-146a Is Largely Responsible for} the Inhibition of IRAK1 and TRAF6

Increased expression of miR-146a induced by TLR ligands in monocytes has been previously observed [11, $22]$. Other cell types that participate in innate immune response can also be linked to miR-146a expression [38]. In order to rule out the role of LPS, lung epithelial A549 cells were treated with IL-1 $\beta$ or LPS. A549 cells did not show increased miR-146a expression in response to LPS, as expected. In contrast, A549 cells showed a very high level of miR-146a expression (42-fold) in response to $1 \mathrm{ng} / \mathrm{ml}$ of IL-1 $\beta$ (fig. 4a), similar to previously observed data [38]. Under similar conditions, miR-132 and miR155 showed little or no change in expression in response to either LPS or IL-1 $\beta$ (fig. $4 b, c)$. The induction of miR146a expression in A549 cells was observed to be depen- 
dent on the IL- $1 \beta$ dose $(0.01,0.1,1.0$ and $10 \mathrm{ng} / \mathrm{ml})$ with a dramatic increase of $>100$-fold with $10 \mathrm{ng} / \mathrm{ml}$ of IL- $1 \beta$ at $24 \mathrm{~h}$ (fig. 4d). As expected, Western blot analysis showed the IRAK1 protein level to be dramatically reduced from 3 to $24 \mathrm{~h}$ after IL- $1 \beta$ stimulation compared to in untreated cells (fig. 4e). The TRAF6 protein level also showed a low-to-moderate reduction in IL-1 $\beta$-treated monocytes 6-24 h after stimulation (fig. 4e). Given the known relationship between miR-146a and these targets, the reduction of IRAK1 and TRAF6 shown here was probably mediated by the induced miR-146a, and it played a major role in establishing IL- $1 \beta$-mediated tolerance and limiting the overproduction of cytokines and/or chemokines.

The Upregulation of miR-146a Can Mimic IL-1 $\beta$

Priming to Induce Tolerance

The preceding results demonstrated IL- $1 \beta$-induced miR-146a expression in THP-1 and A549 cells. This miR146a overexpression correlated with a state of hyporesponsiveness in IL- $1 \beta$-primed cells against a panel of innate immune ligands (fig. $2 \mathrm{a}-\mathrm{c}$ ). Considering the fact that miR-146a plays a critical role in LPS-induced tolerance [11] and cross-tolerance [14], we evaluated the direct role of miR-146a in mediating IL- $1 \beta$-induced tolerance through analysis of data from the transfection of miR146-mimic or inhibitor. In this regard, THP-1 cells were transfected with $100 \mathrm{nM}$ miR-146a-mimic or inhibitor followed by challenge with a set of TLR ligands. Transfection efficiency was confirmed by an overexpression (fig. 5a) or downregulation of mature miR-146a (fig. 5c) compared with an untransfected control, as demonstrated in our previous studies $[11,12,14]$. The effect of miR146a overexpression in THP-1 monocytes on the moderate reduction in expression of both adaptors, IRAK1 and TRAF6, was validated by Immunoblot analysis (62 and $79 \%$ reduction, respectively; fig. $5 \mathrm{~b}$ ). In contrast, THP-1 cells transfected with miR-146a inhibitor and stimulated with IL- $1 \beta$ for $24 \mathrm{~h}$ showed moderately elevated levels of IRAK1 and TRAF6 compared to a mock control (5.48 and 2.55 fold increased, respectively; fig. 5d). Having confirmed that the target molecules IRAK1 and TRAF6 were affected, cytokine production was evaluated. Compared to a mock-transfected control, IL-8 production was significantly $(\mathrm{p}<0.05)$ reduced in miR-146a-mimic transfected THP- 1 cells $24 \mathrm{~h}$ after challenge with LPS (42\%), PGN (40\%) and IL-1 $\beta$ (53\%; fig. 5e). Similarly, RANTES production was significantly decreased $(\mathrm{p}<0.05)$ in miR-146a-mimic transfected THP-1 cells $24 \mathrm{~h}$ after challenge with LPS (31\%), PGN (41\%) or IL-1 $\beta$ (28\%). In con- trast, the production of IL-8 and RANTES was increased significantly $(\mathrm{p}<0.05)$ by $37-59 \%$ and $21-24 \%$, respectively, in miR-146a inhibitor-transfected cells compared to the mock-transfected control (fig. 5e, f). No significant difference in IL- 8 and RANTES was found between the mock control and transfection with commonly used nonspecific miRNA-mimic or miRNA inhibitor (data not shown). Furthermore, similar changes in IL-8 and RANTES levels were observed in A549 cells transfected with miR-146a-mimic or inhibitor and challenged with IL- $1 \beta$; this supports the role of IL- $1 \beta$-induced miR-146a in regulating the production of these cytokines/chemokines. As expected, IL-8 and RANTES decreased by $45-$ $55 \%$ in the miR-146a-mimic transfected A549 cells, while they increased by $28-40 \%$ in the miR-146a inhibitortransfected cells $24 \mathrm{~h}$ after challenge with IL- $1 \beta$ (fig. $5 \mathrm{~g}$, h). Taken together, these results clearly show that IL-1 $\beta$ mediated miR-146a plays an essential role in providing tolerance and cross-tolerance through affecting potential adaptor kinases that can prevent physiological damage from excessive inflammation.

\section{Discussion}

Hyporesponsiveness to LPS challenge, often known as LPS tolerance, is a well-controlled active response, which is orchestrated in order to prevent excessive inflammation [27]. Other TLR ligands such as PGN, Pam and flagellin also show homologous and heterologous (or cross-) tolerance in a similar fashion $[13,14]$. These microbial components induce host innate immunity and the production of various cytokine genes, including chemokines, interferons and interleukins. Cytokines bind and trigger their respective receptors to promote the inflammatory response. Similar to in TLR signaling, an overactivation of cytokine-induced signaling needs to be controlled. In this study, IL-1 $\beta$-induced tolerance is reported, with the aim of understanding its underlying mechanism and broader role in the immune system and biology of cytokine production.

Various regulatory genes, including miRNA, are known to play an important role in immunity $[15,17]$. Recently, the kinetics of various TLR ligand-induced miRNAs, including miR-146a, have been extensively investigated in our laboratory $[11,12,14]$. In this report, among the various cytokines examined, only the monocytes treated with IL- $1 \beta$ or TNF- $\alpha$ showed a rapid and continuous expression of mature miR-146a. In contrast, miR-132, miR-155 and miR-16 did not show any change 


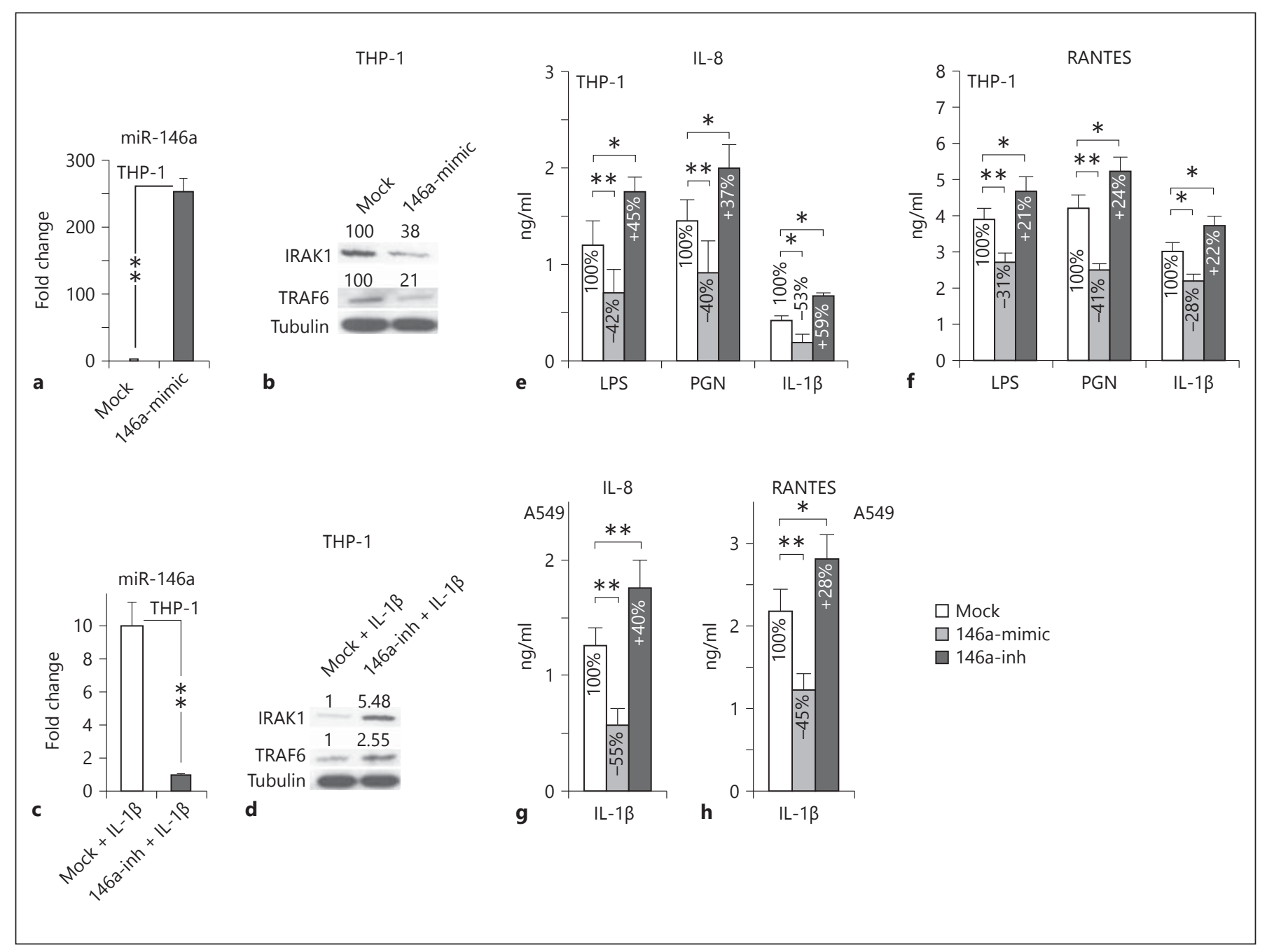

Fig. 5. Transfection of miR-146a alone mimics IL- $1 \beta$ priming in IL-1 $\beta$-induced cross-tolerance whereas inhibition of miR-146a enhances IL- 8 and RANTES production. THP-1 or A549 cells transfected with $100 \mathrm{nM}$ miR-146a-mimic (146a-mimic) or inhibitor (146a-inh) for $24 \mathrm{~h}$, along with mock-transfected controls, were washed with complete growth medium prior to challenge with LPS, PGN or IL-1 $\beta$ for $24 \mathrm{~h}$. Total cellular RNA collected $24 \mathrm{~h}$ after transfection with or without (mock) miR-146a-mimic and miR146a inhibitor were monitored for the level of miR-146a ( $\mathbf{a}$ and c, respectively). Western blot analysis for IRAK1, TRAF6 and tubulin was performed on respective cell lysates (i.e. $\mathbf{b}$ and $\mathbf{d}$ ). ELISA for IL-8 and RANTES protein in supernatants was determined in mock-, miR-146a-mimic- or miR-146a inhibitor-transfected THP-1 after challenge with indicated ligands for $24 \mathrm{~h}$ (e, f). Similarly, IL-8 and RANTES were measured in transfected A549 cells challenged with IL- $1 \beta$ for $24 \mathrm{~h}(\mathbf{g}, \mathbf{h})$. Data are representative of 3 independent experiments and expressed as mean $\pm \mathrm{SD}$. ${ }^{*} \mathrm{p}<0.05$; ** $\mathrm{p}<0.01$, compared with mock-transfected cells. in expression in response to IL- $1 \beta$. As in our LPS stimulation study [11], IL-1 $\beta$ also shows a persistent increase of miR-146a over time. The fact that other innate responseassociated miRNAs do not show such kinetics indicates that the miRNA expression is cytokine-specific to some degree. For example, it has been found that IFN- $\beta$ induces apparently exclusive miR-155 expression in primary murine macrophages [23]. Although miRNAs have been categorized as 'rheostats' that make fine-scale adjust- ments to protein output $[39,40]$, this strong response of miR-146a is more consistent with it playing a dominant role [35].

Microbial components are the potent stimulators of immune response mediators that are controlled by various mechanisms. TLR ligand-induced tolerance has been studied extensively, but cytokine-induced tolerance has received less attention. The ability of IL- $1 \beta$ to induce cross-tolerance shown in this study is congruent with the 
previous study [27]. A rapid cytokine response needs to be controlled to avoid tissue damage. Consistent with this notion, IL-1 $\beta$-primed cells show hyporesponsiveness to a range of innate immune ligands and its own action that can prevent damaging effects from overactivation of the MyD88 signaling cascade. Unlike IL- $1 \beta$, TNF- $\alpha$ showed tolerance only to itself (data not shown); this has been described previously in a similar report [25]. As cytokineinduced tolerance has a positive impact on many immunoregulatory genes, it is crucial to elucidate the mechanism responsible for this interaction. It would not be surprising to discover that more than one negative feedback loop controls this inflammation. While IRAK $1 / 4$ is required for IL- $1 \beta$ production, IRAKM is thought to exert a negative effect on IL-1 $\beta$ production. In another study, IL- $1 \beta$ tolerance was observed in response to TLR 4 downregulation [27]. However, IL-1 $\beta$ tolerance is complex, and our findings show that miR-146a upregulation can affect the TLR/IL-1R pathway in the IL-1 $\beta$-primed monocytes (summarized in fig. 6). TLR and IL-1R signaling activate the MyD88-dependent pathway with the formation of the myddosome, involving the helical assembly of the MyD88-IRAK4-IRAK2/IRAK1 complex [41]. This eventually leads to the activation of TRAF6, NF- $\kappa$ B signaling and inflammatory gene transcription with the production of many cytokines and chemokines, including IL- $1 \beta$. TLR/IL-1R signaling leads to the activation of NF- $\kappa B$, which is known to activate miR-146a production [22]. TLR2 and TLR5 ligands also activate transcription factor CREB and miR-132/-212 production [12]. miR-132/-212 targets IRAK4 [12] whereas miR-146a targets IRAK2/1 and TRAF6 [11]. IRAK4 and IRAK2/1 are critical components of the myddosome, which is in turn critical for the activation of the MyD88-dependent pathway. Thus, IL-1 signaling leads to high levels of miR-146a and blocks TLR signaling, resulting in cross-tolerance to these ligands.

Priming conditions (time and dose) are important factors in rendering innate immune cell tolerance to TLR ligands and cytokines. Compared to LPS, IL- $1 \beta$ requires more priming time to induce tolerance in the same cells [27]. LPS works faster than secreted cytokines. Although the exact reasons underlying these differences are not clear, an LPS concentration of as little as $10 \mathrm{ng} / \mathrm{ml}$ is able to induce tolerance whereas IL- $1 \beta$ is unable to induce a similar effect at such a low concentration. Therefore, we used a higher concentration of priming dose $(\geq 50 \mathrm{ng} / \mathrm{ml})$ in order to observe the tolerance status. LPS appears to be a more potent activator of the TLR/IL-1R pathway than IL-1 $\beta$. For example, LPS was shown to be approximately

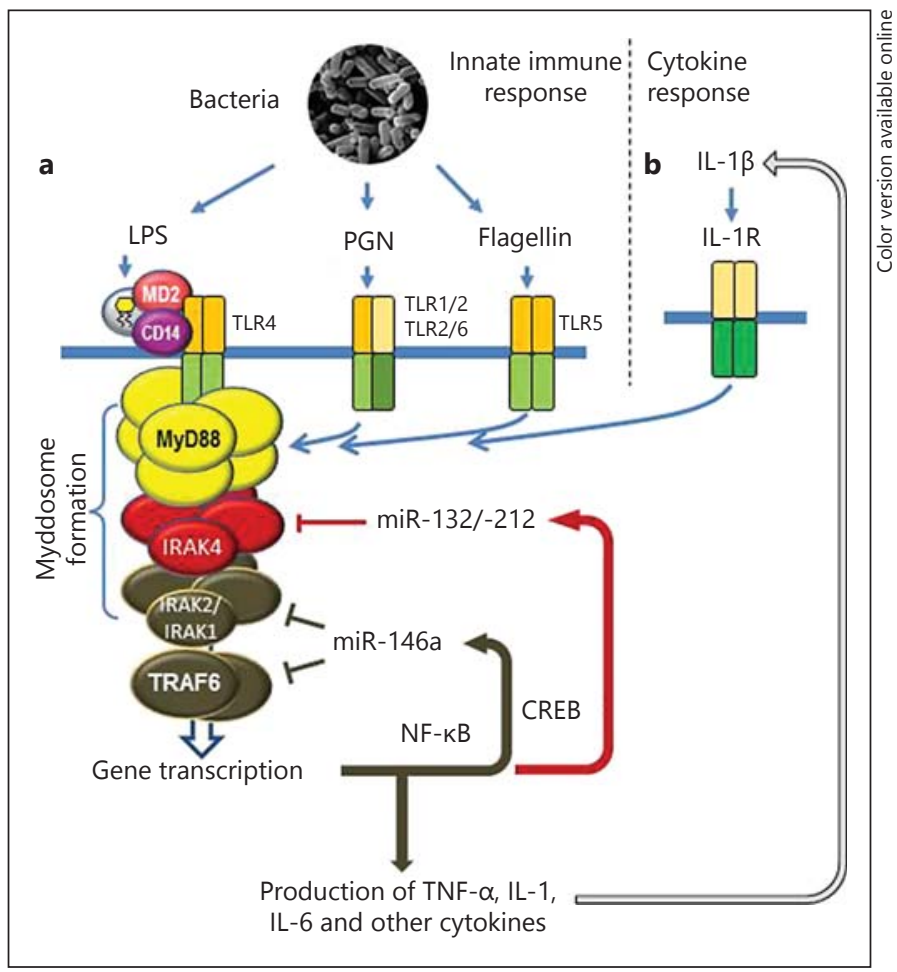

Fig. 6. A schematic summary of IL- $1 \beta$-mediated induction of miR146a targeting IRAK1/TRAF6 in monocytes and it role in regulating cross-tolerance. The cytokine regulatory network is summarized here by illustrating the innate immune response to the bacterial ligands LPS, PGN or flagellin binding to TLRs (a) and the cytokine response to IL-1 $\beta$ binding to IL-1R (b). See the Discussion section in the text.

1,000 times more potent than concanavalin $\mathrm{A}$ (Con $\mathrm{A}$ ) at inducing IL-1 $\beta$ in human monocytes [42]. It could also be attributed to the higher pleiotropic effects of LPS compared with IL- $1 \beta$. In any case, an increase of the priming dose of IL- $1 \beta$ is positively correlated to miR-146a expression and negatively correlated to chemokine and adaptor molecule expression.

In addition to in innate immune cells, miR-146a expression has been investigated in various other cell types to determine whether there is any such expression either at basal level or due to certain stimuli. Perry et al. [38] reported an IL-1 $\beta$-induced downregulated release of IL-8 and RANTES in A549 cells by miR-146a overexpression. Accordingly, A549 cells displayed robust expression of miR-146a even at a very low dose $(0.01$ $\mathrm{ng} / \mathrm{ml}$ ) of IL- $1 \beta$ stimulation, and this correlated with a significant downregulation of chemokine production. In another study, IL-1 $\beta$ treatment increased the expression of miR-146a and vascular endothelial growth fac- 
tor and decreased Smad4 expression in chondrocytes [43]. Thus, IL-1 $\beta$-responsive miR-146a is potentially expressed in many different cell types, supporting its diverse functions. It is acknowledged that further work is needed to address whether the function of miR-146a is conserved in other cell types and disease states. There are many recent publications on the role of miR-146a and readers are referred to recent reviews for its role in neuroprotection [44], normal and malignant hematopoietic cell function [45] and cancer and immunity [46].

The control of IL-1 expression is a critical component of the immune system. IL-1 is an activator of dendritic cells and is involved in the pathogenesis of many diseases with an inflammatory component [47]. Chronic inflammation or expression of these cytokines and receptors at low levels over long periods of time is thought to promote various pathological conditions including autoimmune diseases [48]. Along these lines, it is foreseen that IL-1 $\beta$ induced miR-146a may have direct or indirect effects on these diseases processes. In one of our previous reports, miR-146a expression was found to be associated with proinflammatory experimental periodontal diseases, that may have implications for diseases [49] caused by pathogenic oral bacteria. In other studies, IL- $1 \beta$ induces matrix metalloproteinase-9 in RAW264.7 and A549 cells [50, 51], and this matrix metalloproteinase- 9 clearly plays an important role in periodontal diseases. In this regard, it is interesting to speculate that IL- $1 \beta$-induced tolerance and associated miR-146a expression may have positive effects on periodontal diseases via the adjustment of IL-1 $\beta$ production.
The complete function of miR-146a is not known. Previously, IL-10 [52], TGF- $\beta$ [52], IL-13 [53] and IL- $1 \alpha$ [54] were shown to be involved in the mechanism of refractoriness to LPS. There is no report that these cytokines are able to induce miR-146a expression. However, these are produced by the activation of NF- $\kappa \mathrm{B}$ transcription, so there may be a potential role for miR-146a in these refractory processes.

In summary, the series of evidence reported in this study substantiates the role of miR-146a in IL- $1 \beta$-induced tolerance to TLR ligand challenge. More importantly, miR-146a operates as a negative regulatory feedback mechanism to prevent the destructive consequences of uncontrolled cytokine or chemokine production during the signaling cascade of IL- $1 \beta$ and TLR. Given that the miR-146a response by IL- $1 \beta$ was observed in primary mouse macrophages as well as in human monocytes, it can be argued that it has been demonstrated that miR-146a plays an important physiological role in the regulation of IL- $1 \beta$ signaling. Further investigation of the modulation of the level of miR146a may be critical, in that adjusting miR-146a levels to boost or control TLR activation and cytokine production may be useful tools in therapeutic strategies in the future.

\section{Acknowledgements}

The careful professional editing by John Calise is acknowledged. This work was supported in part by grants from the Lupus Research Institute, the National Institutes of Health (No. AI47859) and the Andrew J. Semesco Foundation, Ocala, Fla., USA. M.A.N. was supported by a NIAMS Rheumatology training grant T32 AR007603.

\section{References}

$>1$ Akira S, Uematsu S, Takeuchi O: Pathogen recognition and innate immunity. Cell 2006 124:783-801.

$\checkmark 2$ Akira S, Takeda K: Toll-like receptor signalling. Nat Rev Immunol 2004;4:499-511.

-3 Schroder K, Zhou R, Tschopp J: The NLRP3 inflammasome: a sensor for metabolic danger? Science 2010;327:296-300.

4 Schroder K, Tschopp J: The inflammasomes. Cell 2010;140:821-832.

$>5$ Netea MG, Nold-Petry CA, Nold MF, Joosten LA, Opitz B, van der Meer JH, van de Veerdonk FL, Ferwerda G, Heinhuis B, Devesa I, Funk CJ, Mason RJ, Kullberg BJ, Rubartelli A, van der Meer JW, Dinarello CA: Differential requirement for the activation of the inflammasome for processing and release of IL-1beta in monocytes and macrophages. Blood 2009;113:2324-2335.
6 Negash AA, Ramos HJ, Crochet N, Lau DT, Doehle B, Papic N, Delker DA, Jo J, Bertoletti A, Hagedorn CH, Gale M Jr: IL-1beta production through the NLRP3 inflammasome by hepatic macrophages links hepatitis $\mathrm{C}$ virus infection with liver inflammation and disease. PLoS Pathog 2013;9:e1003330.

$>7$ Janssens S, Beyaert R: Functional diversity and regulation of different interleukin-1 receptor-associated kinase (IRAK) family members. Mol Cell 2003;11:293-302.

8 Palm NW, Medzhitov R: Pattern recognition receptors and control of adaptive immunity. Immunol Rev 2009;227:221-233.

$>9$ Iwasaki A, Medzhitov R: Regulation of adaptive immunity by the innate immune system. Science 2010;327:291-295.

$>10$ Maedler K, Dharmadhikari G, Schumann DM, Storling J: Interleukin-1 beta targeted therapy for type 2 diabetes. Expert Opin Biol Ther 2009;9:1177-1188.

11 Nahid MA, Pauley KM, Satoh M, Chan EKL: miR-146a is critical for endotoxin-induced tolerance: implication in innate immunity. J Biol Chem 2009;284:34590-34599.

-12 Nahid MA, Yao B, Dominguez-Gutierrez PR, Kesavalu L, Satoh M, Chan EKL: Regulation of TLR2-mediated tolerance and cross-tolerance through IRAK4 modulation by miR-132 and miR-212. J Immunol 2013;190:12501263.

13 Nahid MA, Satoh M, Chan EKL: MicroRNA in TLR signaling and endotoxin tolerance. Cell Mol Immunol 2011;8:388-403.

14 Nahid MA, Satoh M, Chan EKL: Mechanistic role of microRNA-146a in endotoxin-induced differential cross-regulation of TLR signaling. J Immunol 2011;186:1723-1734.
miR-146a Mediates IL-1-Induced

Tolerance
J Innate Immun 2015;7:428-440 DOI: $10.1159 / 000371517$ 
15 O’Neill LA, Sheedy FJ, McCoy CE: MicroRNAs: the fine-tuners of Toll-like receptor signalling. Nat Rev Immunol 2011;11:163-175.

16 Ambros V: The functions of animal microRNAs. Nature 2004;431:350-355.

$\checkmark 17$ Baltimore D, Boldin MP, O’Connell RM, Rao DS, Taganov KD: MicroRNAs: new regulators of immune cell development and function. Nat Immunol 2008;9:839-845.

18 Lodish HF, Zhou B, Liu G, Chen CZ: Micromanagement of the immune system by microRNAs. Nat Rev Immunol 2008;8:120130.

$\checkmark 19$ Hou J, Wang P, Lin L, Liu X, Ma F, An H, Wang Z, Cao X: MicroRNA-146a feedback inhibits RIG-I-dependent type I IFN production in macrophages by targeting TRAF6, IRAK1, and IRAK2. J Immunol 2009;183:2150-2158.

20 Ruggiero T, Trabucchi M, De Santa F, Zupo S, Harfe BD, McManus MT, Rosenfeld MG, Briata P, Gherzi R: LPS induces KH-type splicing regulatory protein-dependent processing of microRNA- 155 precursors in macrophages. FASEB J 2009;23:2898-2908.

-21 Sheedy FJ, Palsson-McDermott E, Hennessy EJ, Martin C, O'Leary JJ, Ruan Q, Johnson DS, Chen Y, O'Neill LA: Negative regulation of TLR4 via targeting of the proinflammatory tumor suppressor PDCD4 by the microRNA miR-21. Nat Immunol 2010;11:141-147.

-22 Taganov KD, Boldin MP, Chang KJ, Baltimore D: NF-kappaB-dependent induction of microRNA miR-146, an inhibitor targeted to signaling proteins of innate immune responses. Proc Natl Acad Sci U S A 2006; 103:1248112486.

-23 O'Connell RM, Taganov KD, Boldin MP, Cheng G, Baltimore D: MicroRNA-155 is induced during the macrophage inflammatory response. Proc Natl Acad Sci U S A 2007;104: 1604-1609.

24 Imaizumi T, Tanaka H, Tajima A, Yokono Y, Matsumiya T, Yoshida H, Tsuruga K, Aizawa-Yashiro T, Hayakari R, Inoue I, Ito E, Satoh K: IFN-gamma and TNF-alpha synergistically induce microRNA- 155 which regulates TAB2/IP-10 expression in human mesangial cells. Am J Nephrol 2010;32:462-468.

25 Ferlito M, Romanenko OG, Ashton S, Squadrito F, Halushka PV, Cook JA: Effect of crosstolerance between endotoxin and TNF-alpha or IL-1beta on cellular signaling and mediator production. J Leukoc Biol 2001;70:821-829.

26 Lindsay MA: microRNAs and the immune response. Trends Immunol 2008;29:343-351.

-27 Alves-Rosa F, Vulcano M, Beigier-Bompadre M, Fernandez G, Palermo M, Isturiz MA: Interleukin-1beta induces in vivo tolerance to lipopolysaccharide in mice. Clin Exp Immunol 2002;128:221-228.

28 Ikeda K, Satoh M, Pauley KM, Fritzler MJ, Reeves WH, Chan EKL: Detection of the argonaute protein Ago2 and microRNAs in the RNA induced silencing complex (RISC) using a monoclonal antibody. J Immunol Methods 2006;317:38-44.
29 Jung HM, Phillips BL, Patel RS, Cohen DM, Jakymiw A, Kong WW, Cheng JQ, Chan EKL: Keratinization-associated miR-7 and miR-21 regulate tumor suppressor reversion-inducing cysteine-rich protein with kazal motifs (RECK) in oral cancer. J Biol Chem 2012;287: 29261-29272.

30 Jung HM, Patel RS, Phillips BL, Wang H, Cohen DM, Reinhold WC, Chang LJ, Yang LJ, Chan EKL: Tumor suppressor miR-375 regulates MYC expression via repression of CIP2A coding sequence through multiple miRNAmRNA interactions. Mol Biol Cell 2013;24: 1638-1648.

31 Livak KJ, Schmittgen TD: Analysis of relative gene expression data using real-time quantitative PCR and the 2-delta delta $\mathrm{C}(\mathrm{T})$ method. Methods 2001;25:402-408.

- 32 Furuta K, Chan EKL, Kiyosawa K, Reimer G, Luderschmidt C, Tan EM: Heterochromatin protein HP1Hsbeta (p25beta) and its localization with centromeres in mitosis. Chromosoma 1997;106:11-19.

-33 Moreno RD, Ramalho-Santos J, Chan EKL, Wessel GM, Schatten G: The Golgi apparatus segregates from the lysosomal/acrosomal vesicle during rhesus spermiogenesis: structural alterations. Dev Biol 2000;219:334-349.

34 Ceribelli A, Yao B, Dominguez-Gutierrez PR, Nahid MA, Satoh M, Chan EKL: MicroRNAs in systemic rheumatic diseases. Arthritis Res Ther 2011;13:229.

35 Ceribelli A, Satoh M, Chan EKL: MicroRNAs and autoimmunity. Curr Opin Immunol 2012;24:686-691.

- 36 Ikejima T, Okusawa S, Ghezzi P, van der Meer JW, Dinarello CA: Interleukin-1 induces tumor necrosis factor (TNF) in human peripheral blood mononuclear cells in vitro and a circulating TNF-like activity in rabbits. J Infect Dis 1990;162:215-223.

37 Tiwari RL, Singh V, Singh A, Barthwal MK: IL-1R-associated kinase-1 mediates protein kinase C-delta-induced IL-1beta production in monocytes. J Immunol 2011;187:26322645.

38 Perry MM, Moschos SA, Williams AE, Shepherd NJ, Larner-Svensson HM, Lindsay MA: Rapid changes in microRNA-146a expression negatively regulate the IL-1beta-induced inflammatory response in human lung alveolar epithelial cells. J Immunol 2008;180:56895698.

39 Baek D, Villen J, Shin C, Camargo FD, Gygi SP, Bartel DP: The impact of microRNAs on protein output. Nature 2008;455:64-71.

40 Selbach M, Schwanhausser B, Thierfelder N, Fang Z, Khanin R, Rajewsky N: Widespread changes in protein synthesis induced by microRNAs. Nature 2008;455:58-63.

41 Lin SC, Lo YC, Wu H: Helical assembly in the MyD88-IRAK4-IRAK2 complex in TLR/IL1R signalling. Nature 2010;465:885-890.
42 Jessop JJ, Hoffman T: Production and release of IL-1 beta by human peripheral blood monocytes in response to diverse stimuli: possible role of 'microdamage' to account for unregulated release. Lymphokine Cytokine Res 1993;12:51-58.

43 Li J, Huang J, Dai L, Yu D, Chen Q, Zhang X, Dai K: miR-146a, an IL-1beta responsive miRNA, induces vascular endothelial growth factor and chondrocyte apoptosis by targeting Smad4. Arthritis Res Ther 2012;14:R75.

44 Ouyang YB, Xu L, Yue S, Liu S, Giffard RG: Neuroprotection by astrocytes in brain ischemia: importance of microRNAs. Neurosci Lett 2014:565:53-58.

45 Zhao JL, Starczynowski DT: Role of microRNA-146a in normal and malignant hematopoietic stem cell function. Front Genet 2014;5:219.

46 So AY, Zhao JL, Baltimore D: The Yin and Yang of microRNAs: leukemia and immunity. Immunol Rev 2013;253:129-145.

-47 Ceppi M, Pereira PM, Dunand-Sauthier I, Barras E, Reith W, Santos MA, Pierre P: MicroRNA-155 modulates the interleukin-1 signaling pathway in activated human monocyte-derived dendritic cells. Proc Natl Acad Sci U S A 2009;106:2735-2740.

48 Dinarello CA: Immunological and inflammatory functions of the interleukin-1 family. Annu Rev Immunol 2009;27:519-550.

49 Nahid MA, Rivera M, Lucas A, Chan EKL, Kesavalu L: Polymicrobial infection with periodontal pathogens specifically enhances microRNA miR-146a in ApoE-/- mice during experimental periodontal disease. Infect Immun 2011;79:1597-1605.

50 Yoo HG, Shin BA, Park JS, Lee KH, Chay KO Yang SY, Ahn BW, Jung YD: IL-1beta induces MMP-9 via reactive oxygen species and NF-kappaB in murine macrophage RAW 264.7 cells. Biochem Biophys Res Commun 2002;298:251-256.

51 Cheng CY, Kuo CT, Lin CC, Hsieh HL, Yang CM: IL-1beta induces expression of matrix metalloproteinase-9 and cell migration via a c-Src-dependent, growth factor receptor transactivation in A549 cells. Br J Pharmacol 2010;160:1595-1610.

52 Randow F, Syrbe U, Meisel C, Krausch D, Zuckermann H, Platzer C, Volk HD: Mechanism of endotoxin desensitization: involvement of interleukin 10 and transforming growth factor beta. J Exp Med 1995;181:18871892.

53 Muchamuel T, Menon S, Pisacane P, Howard MC, Cockayne DA: IL-13 protects mice from lipopolysaccharide-induced lethal endotoxemia: correlation with down-modulation of TNF-alpha, IFN-gamma, and IL-12 production. J Immunol 1997; 158:28982903.

54 Leon P, Redmond HP, Shou J, Daly JM: Interleukin 1 and its relationship to endotoxin tolerance. Arch Surg 1992;127:146-151. 